\title{
Standpunt NVVG en GAV over het GR-advies ME/CVS
}

\author{
Namens het NVVG- en GAV-bestuur: Rob Kok, Monique Tolsma-Piegza
}

De kwaliteit van het GR-advies ${ }^{1}$ schiet op een aantal onderdelen tekort: sommige stellingen en conclusies missen een wetenschappelijke onderbouwing en zijn gekleurd door hoe (een deel van) de patiënten daarover denkt. Wij missen de benodigde transparantie over gemaakte keuzes ten aanzien van bijvoorbeeld het selecteren van de onderzoeksliteratuur. $^{2}$

De NVVG en de GAV vinden het vreemd dat zij niet zijn uitgenodigd om deel uit te maken van de commissie, juist omdat de Tweede Kamer vroeg om de invloed van ME/ CVS op maatschappelijke participatie en de begeleiding van patiënten in het advies te betrekken. En de beoordeling daarvan behoort toch juist tot de competentie van de verzekeringsartsen, zowel in het publieke als private domein? Temeer daar wij eerder, evenals bedrijfsartsen, wél betrokken zijn geweest bij de totstandkoming van de multidisciplinaire richtlijn CVS uit 2013, evenals de andere stakeholders (inclusief patiënten). Afwezigheid van artsen in het domein arbeid en gezondheid binnen de commissie is in dit kader onbegrijpelijk en doet ook afbreuk aan de kwaliteit van het advies.

De NVVG en de GAV zijn het nadrukkelijk niet eens met de vierde en laatste aanbeveling van de commissie gericht aan medisch beoordelaars. Zo wordt de suggestie gewekt dat, als de patiënt geen heil ziet in CGT of oefentherapie, hij of zij met rust gelaten moet worden. Dat roept verbazing op. Want, hoewel er geen op de oorzaak gerichte behandeling is voor ME/CVS - een duidelijke oorzaak is tot op heden niet gevonden - mag van een patiënt worden verwacht dat hij of zij een behandeling volgt die zijn of haar klachten kan verminderen. Deze schadebeperkingsplicht geldt voor alle cliënten die een claim op een uitkering doen. Doorgaan met een behandeling die niet effectief is, is zelden zinvol, maar de huidige formulering door de GR is onnodig restrictief. Ook de kwalificatie van ME/CVS als een ernstige aandoening die gepaard gaat met substantiële beperkingen wekt verbazing op: over nagenoeg geen enkele ziekte wordt een zo categorische uitspraak gedaan. Zoals bij veel aandoeningen geldt ook voor patiënten met ME/CVS dat er patiënten zijn die aangeven ernstige beperkingen te ondervinden in hun dagelijks leven, maar er zijn er ook voldoende voor wie dat niet geldt. Verzekeringsartsen verrichten dan ook een individuele beoordeling die recht doet aan deze beperkingen. Wij kunnen niet op voorhand aannemen dat die beoordeling per definitie tot volledige (duurzame) arbeidsongeschiktheid moet gaan leiden. Dat zou ook niet gezondheidsbevorderend zijn, integendeel. Hiermee dreigen we mensen volledig (en blijvend) buiten de maatschappij te plaatsen, wat absoluut niet past in de participatiegedachte en hen zelfs de mogelijkheid tot arbeid ontneemt, één van de fundamentele Rechten van de Mens.

De NVVG en GAV onderschrijven de aanbeveling voor meer onderzoek naar ME/CVS. Het is belangrijk dat onderzoek naar de oorzaak van ME/CVS wordt voortgezet omdat dit de sleutel is naar hopelijk niet alleen betere diagnostiek, maar ook een effectieve(re) behandeling. Met de andere drie aanbevelingen van de commissie zijn wij het niet eens.

Onze conclusie is dat het huidige GR-advies voor professionals in onze beroepsgroep(en) niet werkbaar is. Wij stellen als beroepsverenigingen voor om dit advies mee te nemen bij de herziening van de multidisciplinaire richtlijn uit 2013, zoals reeds was beoogd in 2017. Tot deze herziening is gerealiseerd blijft de door ons geautoriseerde richtlijn uit 2013 onveranderd van kracht. Deze richtlijn prevaleert boven zowel het GR-advies als het UWV-bericht hierover twee dagen later, zo leert ook juridische ruggespraak. Concreet betekent dit dat, als een verzekeringsarts lege artis zijn/haar beoordeling verricht, conform de multidisciplinaire CVS-richtlijn, het enkele feit dat hij/zij de aanbevelingen van de GR dan wel de UWV-mededeling niet volgt, hem/haar niet (tucht)rechtelijk kan worden verweten. ${ }^{3}$

\section{Bronnen}

1. https://www.gezondheidsraad.nl/nl/taak-werkwijze/ werkterrein/optimale-gezondheidszorg/mecvs.

2. https://www.nvvg.nl/nieuws/nieuws-nvvg/standpuntnvvg-en-gav-gr-advies-mecvs-niet-werkbaar-in-praktijk/.

3. https://www.nvvg.nl/nieuws/nieuws-nvvg/standpuntnvvg-en-gav-prevaleert-boven-zowel-het-gr-advies-als-hetuwv-bericht/. 